\title{
American Fiction Today
}

By

Rolf Lundén

Uppsala University

The world is much more diverse and pluralistic today than ever before. The old values - Christianity, tradition, the family unit have ceased being the norm. Even science and money are no longer trusted the way they once were. To fill the void, innumerable new ideas and values come into a usually rather short-lived existence. A frantic search for new values, which may replace the old ones, is apparent in the United States as well as elsewhere, taking expressions like a political commitment, the drug culture, Beatniks, Hippies, sex cult and pornography, oriental philosophy, meditation, occultism, the ecological movement, sensitivity training or encounter groups. The latest is est.

In addition, new centers of concern are forced upon us through television and newspapers. The world around us seems to become more and more fragmented, more and more chaotic. No wonder that the individual is confused; no wonder that he has a frightening sense of alienation.

Since literature is a reflection of what is taking place in society, it is hardly surprising that American fiction after World War II is characterized by variety. The period may seem more heterogeneous than it actually is, since it is difficult to detect a pattern while we are still part of that pattern; only in retrospect do we see the picture clearly. But there is also a factual diversity, which maybe is the pattern of this literary period. There are numerous ideas, genres, modes of expression which cannot be united into a neat little formula to be used by critics and literary historians.

When faced with the task of presenting American fiction today, one consequently soon realizes the need to limit oneself. One could choose to speak about different themes in contemporary fiction: 
alienation, the search for identity, existentialism (as Lehan has done), the landscape of nightmare (as Baumbacli has done), or celebration (as Rupp has done). One could also talk about various genres: Beat fiction, the Jewish novel, Black fiction, New Journalism, the Southern novel, the fiction of the Indians, or as they are called today, the Native Americans. I have decided to limit myself to talk about a group of writers who are often referred to as the Fabulators. Doing that, I am aware of neglecting other important aspects of contemporary American fiction, aspects which we may discuss later on maybe in the general discussion.

Robert Scholes used this term, "the Fabulators," to characterize a group of American (and British) fiction writers after World War II who were particularly interested in renewing theform of the novel and the short story. Tony Tanner's term for what these writers are doing is "foregrounding," i.e. they draw attention to their own narrative technique by means of artifice and innovative language. The Fabulators are not an organized group in any sense, but these writers rather share a similar view of literature and reality. There is one exception though, seven or eight of the less well-known fabulators have united into an organized group called The Fiction Collective. The leader of the group, and the best known of them, is Ronald Sukenick. Others are Russell Banks and Mark J . Mirsky. But most of the Fabulators are individualists; it would be against their sense of freedom to organize into a collective like this. The grand old man of the Fabulators, and to whom many of the younger writers have turned for inspiration, is Vladimir Nabokov. The most popular of them is Kurt Vonnegut, Jr., whose books are selling by the millions, and who, partly because of that, is being accused of superficiality. The most serious, and perhaps also the most gifted of them seems to be John Barth.

These authors not only look upon literature in a similar way, most of them are also, interestingly enough, university professors. Barth teaches English at Penn State, Sukenick at Cornell, John Hawkes at Brown. William H. Gass, author of Omensetter's Luck and The Tunnel, teaches philosophy at Washington University, St. Louis. These two roles of teacher and author can be united because they have a detached, analytical approach to literature.

The Fabulators feel that American fiction suffersfrom "exhausted possibilities" as Barth says in his by now classic article "The Literature of Exhaustion." What Barth means is not "anything so tired as the subject of physical, moral, or intellectual decadence, only the 
used-upness of certain forms or exhaustion of certain possibilities by no means necessarily a cause for despair."1 They experience that the traditional way of writing, so-called realistic or naturalistic fiction, has worn itself out. Barth and others feel the ultimacies of the era, an urge to attain the ultimate. One such ultimacy is silence, which Beckett seems to be striving for; this ultimacy has already been attained, however, as Barth points out, by Elbert Hubbard in the 19th century in his "Essay on Silence" which consists of nothing but blank pages. There is a Swedish counterpart, Carl-Frederik Reutersvard's Prix Nobel, which contains only various punctuation marks. Barth says in his essay that 'If you happened to be Vladimir Nabokov, you might address that felt ultimacy by writing Pale Fire: a fine novel by a learned pedant, in the form of a pedantic commentary on a poem invented for the purpose." 2

One of the reasons why the possibilities have become exhausted is the growing impact of $\mathrm{TV}$ and cinema. The writer of today cannot compete with these media when it comes to telling a traditional story. A picture says more than a thousand words. So the author feels compelled to try other ways, and the way the Fabulators have chosen is a return to Design and unrestricted Imagination. This is what Robert Coover speaks about in the Preface to "Seven Exemplary Fictions" where he addresses Cervantes, who, as a renewer of fiction, has come to be a model for many Fabulators:

Like you, we, too, seem to be standing at the end of one age and on the threshold of another. We, too, have been brought into a blind alley by the critics and analysts; we, too, suffer from a "literature of exhaustion," though ironically our nonheroes are no longer tireless and tiresome Amadises, but hopelessly defeated and bed-ridden Quixotes. ... The return to Being has returned us to Design, to microcosmic images of the macrocosm, to the creation of Beauty within the confines of cosmic or human necessity, to the use of the fabulous to probe beyond the phenomenological, beyond appearances, beyond randomly perceived events, beyond mere history. But these probes are above all-like your Knight's sallies-challenges to the assumptions of a dying age, exemplary adventures of the Poetic Imagination, high-minded journeys towards the New World and never mind that the nag's a pile of bones. ${ }^{3}$

Coover here points to a search for poetic freedom, and John Hawkes, in "Notes on the Wild Goose Chase," also stresses the kinship between the writer of experimental fiction and the poet: "Like the poem, the experimental fiction is an exclamation of psychic materials which come to the writer all readily distorted, prefigured in that nightly inner schism between the rational and the absurd."4

This schism between the "rational and the absurd" brings us to 
the way the Fabulators look upon reality. The "realists" pretended to portray "a slice of life," i.e. the truth. And the readers believed them. As William H. Gass says in his article "A True Lie-minded Man": "For most people fiction is history; fiction is history without tables, graphs, dates, imports, edicts, evidence, laws; history without hiatus - intelligible, simple, smooth. ".5 But it is shocking to discover, Gass says, that fiction is "made of words, and merely words." A novel is not "a slice of life"; it is an invention from the first page to the last.

But the Fabulators do not stop there. Not only do they question the "realism" of "realistic" fiction, they question what we call reality, the phenomenological world. Sukenick says in his novel Out: "The world is pure invention from one minute to the next." These authors feel that there is no sharp dividing-line between illusion and reality. To show this ambiguity they often use mirrors, often refracted as in Nabokov, reflections, and anagrams. For this reason they are also fond of stories-within-stories. As Barth puts it: "When the characters in a work of fiction become readers or authors of the fiction they are in, we're reminded of the fictitious aspect of our own existence."6 The reader asks himself: What is invented, what is not? Who invents whom? In Barth's Chimera, the genie invents Scheherazade while she invents him at the same time. In "Menelaid" in Lost in the Funhouse, Barth uses an intricate pattern of seven stories within the other stories. Kurt Vonnegut invents, in Breakfast $₫$ Champions, a narrator, Philboyd Studge, who invents the science-fiction-writer Kilgore Trout, whose stories in turn are re-told in the book.

The only reality these writers seem to recognize is the actual writing of their fiction, the creative process. William $\mathrm{H}$. Gass says that the following quotation from Colette is true for most serious writers: "The only reality is the translation of one's ideas into rhythm and beautiful movements."' It is not surprising then to find that the Fabulators write so much metafiction, i.e. stories which deal with the creative process, with narrative technique in general, or particular problems in telling stories. This theme is maybe most often discussed by Barth, but also by Nabokov, Vonnegut, Coover and others.

Another consequence of this way of looking upon reality is that these writers feel free to fabulate. Whatever they invent - often incredible, absurd things - will be as true as the world around us, which in their view is equally absurd. They feel free to invent 
without any models. Gass states: "Models interfere with the imagination." The setting of Omensetter's Luck is an Ohio river town. Gass says: "I made it up. I know nothing of Ohio river towns and care less... . Omensetter isn't really set in Ohio; that is the point.".8 Sometimes the fruit of their imagination has the appearance of reality with an abundance of invented historical facts, documents, footnotes, etc., as in Pynchon's The Crying of Lot 49. The author creates a world which, he seems to say, is more real than the world around us. The role of the artist is the creator of the world; the painting described by Pynchon in the beginning of The Cirying $\delta$ Lot 49 becomes a metaphor of that role:

... in the central painting of a triptych, titled "Bordano el Manto Terrestre," were a number of frail girls with heart-shaped faces, huge eyes, spun-gold hair, prisoners in the top room of a circular tower, embroidering a kind of tapestry which spilled out the slit windows and into a void, seeking hopelessly to fill the void: for all the other buildings and creatures, all the waves, ships and forests of the earth were contained in this tapestry, and the tapestry was the world. ${ }^{9}$

When it comes to the actual telling of their stories, this belief in themselves as creators becomes a working principle. They put themselves in the center of their fiction, all the time visible like the frail girls weaving in their tower. By doing this they destroy the traditional way of telling a story. For instance, a fabulator very often reveals from the start what the climax or the resolution of the story will be, thereby exploding the story of suspense, pricking the balloon. In a similar way he explains the title and the symbols. In The Floating Opera, Barth describe: two dogs copulating in front of a casket. The reader, always eager to see symbols, thinks of life and death and feels proud at discovering this. Then Barth says: "Nature, coincidence, can be a heavy-handed symbolizer. She seems at times fairly to club one over the head with significances such as this clumsy 'life-in-the-face-of-death' scenario, so obvious that it was embarrassing." 10 The reader feels cheated and foolish. Another common way of breaking down the traditional narrative technique is to avoid chronological order. Vonnegut lets Billy Pilgrim in Slaughterhouse-Five become "unstuck" in time and can through that device tell the story any way he prefers to.

The author is always in charge. He intrudes in the story, not only through an invented narrator, but also in his own person. Vonnegut says about a man with diarrhea: "That was me. That was the author of this book." In the middle of Snow White, Donald Barthelme asks the reader to answer "yes" or "no" to a list of ques- 
tions: "Do you like the story so far? Does Snow White resemble the Snow White you remember? Have you understood, in reading to this point, that Paul is the prince-figure?"11 The reader is always kept aware of the fact that he is reading a book, that this is the reality he is facing. Other devices are also used to draw attention to the artifice of the book: allusion, alliteration, and puns.

The Fabulators do not believe that their message is new. They rather feel that everything has already been said. To use a quotation that Barth refers to: "all writers are more or less faithful amanuenses of the spirit, translators and annotators of pre-existing archetypes." 12 But man has grown so used to the message that he does not understand it. The Fabulators break down the form and thereby wake the reader up, shock him into recognition, make him see the old message in a new light. This would explain the abundance of parodies and re-tellings of well-known stories: Barth's The Sot-weed Factor is based on Ebenezer Cooke's poem. Barthelme retells Snow White, Coover the stories of Hansel and Gretchen, of Noah and of Joseph and Mary in Pricksongs and Descants, Barth the stories of Scheherazade, Perseus, and Bellerophon in Chimera.

The detachment of the Fabulators to their material also results in a lack of emotional involvement in the reader. These authors want the reader to keep a distance to the story told, to analyze the problems posed, and maybe take a stand. The achievement of the traditional realistic novel was that it fooled the reader into an illusion of life, into an emotional involvement in character: and plot that blinded him. This explains the absence of round characters in the works of the Fabulators. Their protagonists are types, and intentionally so, compared to those of naturalistic fiction. One may just compare Mailer's The Naked and the Dead to Vonnegut's Slaughterhouse-Five, both about World War II, to see the difference. Humor, very common among these experimental writers, is used in a similar way, to blow to pieces the blinding emotionalinvolvement.

How will American fiction develop in the future? Robert Coover says that "we seem to be standing at the end of one age and on the threshold of another." But this literature of the ultimate cannot be taken much further and at the same time retain coherence.

Robert Scholes has recently published an Essay on Fiction of the Future, Structural Fabulation (1975), in which he thinks that fiction will be what we now loosely call sciencefiction. Reviewing a recent 
novel, Beyond the Bedroom Wall by Larry Woiwode, John Gardner believes that fiction will turn back towards the realistic family chronicle, linking that genre to experiments in form. Gardner also believes in a return to emotion, not Victorian sentimentality, but he says: "it is a wonderful thing, it seems to me, to laugh and weep one's slow way through an enormous intelligent novel tracing out the life of a family."

\section{John Gardner also said in the same review:}

In our age, magicians explain their tricks, even print them in magazines, and our admiration soars. Hence the movement in literature from realistic selfconsciousness to "fabulation": we no longer pretend to be omniscient authorities on doctors, fishermen, prime ministers, etc. We tell grand lies with gusto, flaunting our art and trickery ...., making up, almost wholly from imagination, rocket-men, dragons and also postal clerks. The construction of the novel, once hidden from view like the machinery on a film set, becomes part of the pleasure (like the exposed machinery in a Fellini film). How is Galsworthy, I ask you, to compete with that?

But on the other hand how can such gim-crackery compete with Galsworthy? When self-doubt, alienation and fashionable pessimism become a bore and what's worse, a patent delusion, how does one get back to the big emotions, the large and fairly confident life affirmations of an Arnold Bennett, a Dickens, a Dostoevsky ?13

Gardner is pointing to what he feels are the negative aspects of the fiction of the Fabulatore. I would like to conclude this introduction by asking a few questions which may be dealt with in the general discussion later:

Does fabulation, the stressing of style and form, help us see the message more clearly, or does it become an obstacle which prevents us from doing so? Is fabulation a game only, a literary cross-word puzzle, a new form of art-for-art's sake, or does it give us a deeper understanding of ourselves and the world around us? Is fabulation a new form of entertainment, Woodehouse on a high intellectual level? Is fabulation only for a cultural elite, only for the few initiated who understand the clever devices and the literary allusions? Is it enough today to write fiction about writing fiction? Aren't there more urgent questions to be dealt with in this era, when the world is on the verge of ruin?

\section{N O T E S}

1 John Barth, "The Literature of Exhaustion," The American Novel Since World War 11, ed. with an introduction by Marcus Klein (Greenwich, Conn.: Fawcett Premier, 1969), p. 267.

2 Ibid., p. 275. 
3 Robert Coover, "Seven Exemplary Fictions," Pricksongs $\xi^{\circ}$ Descants (London: Picador, 1973), pp. 61-62.

4 John Hawkes, "Notes on the Wild Goose Chase," The American Novel Since World War II, p. 249.

5 William H. Gass, "A True Lie-Minded Man," The American Novel Since World War II, p. 264.

6 John Barth, "The Literature of Exhaustion," p. 276.

7 Interview with William H. Gass, in Joe David Bellamy, The New Fiction: Interviews with Innot'atit'e American Writers (Urbana: University of Illinois Press, 1974), p. 34.

8 Ibid., p. 36. Ronald Sukenick has the following dialogue in $U p$ (New Yorli: Dell, 1970): p. 217:

"Well that's what art is all about, right? The discovery of reality."

"No. The invention of reality."

"You mean to say that a perfect description of a rose isn't in some sense a discovery of reality?"

"No. I mean it isn't art. We aren't botanists. Art seeks avital connection with the world that, to stay alive, must be constantly reinvented to correspond with our truest feelings."

9 Thomas Pynchon, The Crying o Lot 49 (New Yorli: Bantam, 1967), p. 10.

10 John Barth, The Floating Opera (New Yorli: Bantam, 1972), p. 106.

11 Donald Barthelme, Snow White (New Yorli: Bantam, 1968), pp. 82-83.

12 John Barth, "The Literature of Exhaustion," p. 277. Sukenicli writes in $U p$ (p. 56): "When a creative writing student asks me what to write about I answer: Amuse yourself. There's nothing to write about."

13 John Gardner, Review of Larry Woiwode's Beyond the Bedroom Wall, The New York Times Book Revieze, September 28, 1975, p. 1. 